\title{
DEVELOPMENT OF A MODEL FOR SURVEILLANCE AND CONTROL OF FLAVIVIRUSES IN HUMAN POPULATION
}

\author{
Vesna Milošević ${ }^{1^{*}}$, Sandra Stefan Mikić ${ }^{2}$, Dušan Petrić ${ }^{3}$, Tamaš Petrovićc \\ Jelena Radovanov ${ }^{1}$, Gordana Kovačević ${ }^{1}$, Ivana Hrnjaković Cvjetković ${ }^{1}$ \\ ${ }^{1}$ Institute of Public Health of Vojvodina, Novi Sad \\ ${ }^{2}$ Clinical Centre of Vojvodina, Novi Sad \\ ${ }^{3}$ Faculty of Agriculture, University of Novi Sad, \\ ${ }^{4}$ Scientific Veterinary Institute "Novi Sad” Novi Sad,
}

\begin{abstract}
The aim of this study is development of a model for monitoring and control of vector-transmitted diseases, which manifest increasing tendency during the last few decades. The main infection reservoirs are domestic and wild animals as well as various birds, and the disease is transmitted to humans indirectly - by vectors. Recently detected epidemics of Dengue virus, Chikungunya and West Nile virus in countries where these diseases are not common strongly indicate the expansion of infections transmitted by mosquitoes and other vectors, and are the consequence of climatic changes, international trade and travelling. Currently, there are neither vaccines nor specific antiviral therapy for these infections, while the efforts put on vector control did not halt the rapid increase and global spread of the disease. Serological studies and molecular investigation on humans, mosquitoes, horses and birds have suggested the activity of flaviviruses in Serbia. The obtained information on flavivirus infections in our region are of use in modelling the control and vector monitoring and the prevention of these infections in humans.
\end{abstract}

Keywords: flavivirus infections, diagnosis, prevention

${ }^{1^{\star}}$ E mail: vesna.milosevic@izjzv.org.rs 


\section{IZRADA PREDLOGA MODELA ZA PRAĆENJE I KONTROLU FLAVIVIRUSA U HUMANOJ POPULACIJI}

Vesna Milošević ${ }^{1}$, Sandra Stefan Mikić ${ }^{2}$, Dušan Petrić , Tamaš Petrović $^{4}$, Jelena Radovanov ${ }^{1}$, Gordana Kovačević ${ }^{1}$, Ivana Hrnjaković Cvjetković ${ }^{1}$

${ }^{1}$ Institut za javno zdravlje Vojvodine, Novi Sad

${ }^{2}$ Klinički centar Vojvodine, Novi Sad

${ }^{3}$ Naučni institut za veterinarstvo"Novi Sad", Novi Sad

${ }^{4}$ Poljoprivredni fakultet Univerziteta u Novom Sadu, Novi Sad

\section{Kratak sadržaj}

Cilj rada je izrada predloga modela za praćenje i kontrolu transmisivnih vektorskih bolesti koje su poslednjih nekoliko decenija u porastu. Rezervoari su divlje i domaće životinje i raznovrsne ptice, a na čoveka se prenose posredno-vektorima. Nedavno uočene epidemije Denga virusom, Čikungunja i West Nile virusom u zemljama u kojima ove bolesti nisu uobičajene, potvrda su sve većeg širenja infekcija komarcima i drugim vektorima, a posledica su klimatskih promena u okruženju, rasprostranjenom trgovinom i putovanjima. Trenutno ne postoje vakcine niti specifična antivirusna terapija za ove infekcije, a napori da se konrolišu vektori nisu sprečili brzi porast i globalno širenje zaraze. Serološke studije i molekularna ispitivanja sprovedena kod ljudi, komaraca, konja i ptica ukazale su na aktivnost flavivirusa u Srbiji. Dobijene informacije o kretanju flavivirusnih infekcija u našoj sredini od koristi su u modeliranju kontrole i praćenju vektora i preveniranju infekcija kod čoveka.

Ključne reči: flavivirusne infekcije, dijagnoza, prevencija

\section{INTRODUCTION}

The aim of this paper is development of a model proposed for monitoring and control of vector-transmitted diseases, which demonstrated increased incidence in the last decades. The main infection reservoirs are domestic and wild animals as well as various birds, and the disease is transmitted to humans indirectly - by vectors. Recently detected epidemics of Dengue virus, Chikungunya and West Nile virus in countries where these diseases were not present before, are the signal of a potential threat of the spread of infections transmitted by mosquitoes and other vectors, and are in close connection with climatic changes in the area, international trade and travelling.

In the last decades, mosquito-transmitted flavivirus infections have gai- 
ned substantial public health importance because of wide geographical distribution, epidemic emergence outside of the endemic areas and difficult forms of diseases that may cause. Flaviviridae family encompasses 53 virus species, among which Dengue and West Nile virus, transmitted by mosquitoes, and Tick-borne encephalitis virus (TBEV), transmitted by ticks, are of particular importance.

Dengue (DEN) is a viral infection caused by an ARBO virus from Flaviviridae family. Transmission to humans occurs by a mosquito from the genus Aedes, mostly Aedes aegypti, and less frequently by Aedes albopictus. Dengue has 4 serotypes: 1 - 4, which produce cross-immunity. It causes an illness that ranges from mild to very severe that is manifested by a shock syndrome and hemorrhagic fever with lethal outcome. Currently, there are neither vaccines nor specific antiviral therapy. Dengue is endemic in at least 100 countries all over the world (Asia, Africa, American continent, the Caribbean, Pacific). According to the World Health Organization (WHO), 50-100 millions people in the world are infected by Dengue virus annually. (http://www.who.int/csr/ resources/publications/dengue/Denguepublication/en/) Efforts aimed at vector control did not prevent rapid increase of this dangerous disease and its spread throughout the world. Risk factors for the increase of Dengue infection incidence are migration of population from undeveloped endemic countries into developed countries, increase in travelling and tourists' number, urbanization that favours the spread of urban mosquitoes such as Aedes albopictus. A danger of Dengue fever is now evident even in Europe, since first autochthonous cases were registered in France and Croatia in 2010 (Gjenero et al., 2011; La Ruche et al., 2010). Serological and entomological investigation on Pelješac peninsula in Croatia, where first autochthonous cases of Dengue were registered, proved the presence of specific Dengue antibodies in healthy residents and the domination of Aeds albopictus species in analyzed mosquitoes (Gjenero et al., 2011).

West Nile virus fever is a zoonosis caused by an ARBO virus from Flaviviridae family and Japanese encephalitis serogroup. Virus reservoirs in natural environment include hundreds of bird species belonging to 20 families in the order of Passeriformes, while vectors involve about 60 mosquito species, mostly from the genus Culex. Other vertebrates may be infected with this virus; however, their role in the transmission has not yet been elucidated ( $\mathrm{Hr}-$ njakovic-Cvetkovic et al., 2014). Under favourable environmental conditions, viral turnaround cycle is intensified and may lead to infection in horses and humans, which are accidental hosts unsuitable for infecting mosquitoes. In most cases, the infection is asymptomatic or proceeds as a mild condition, but 
some $1 \%$ of infected individuals develop a neurological disease - meningitis, encephalitis and myelitis that rapidly progress to severe conditions with fatal outcomes, especially in the elderly (Mostashari et al., 2001). Sporadic cases and epidemics were recorded in Africa, Middle East, Europe and Asia. Since 1999, when first human cases were recorded in New York, infection has rapidly spread across USA and has become endemic in North America. This spread has instigated intensive research in the area of diagnostics and production of human vaccine. Vaccines for horses have already been developed, whereas those for human use have not yet been registered. Serological studies and molecular investigations in humans, mosquitoes, horses and birds suggested the activity of the virus in Serbia (Petric et al., 2012; Lupulovic et al., 2011; Petrovic et al., 2012). Since 2012, when first epidemics was registered in Serbia (Popović et al., 2012), human cases have been reported every year in the period from August to October. Until October 20, 2014, the Institute of Public Health of Serbia "Slobodan Jovanović Batut" recorded 56 laboratory-confirmed cases of human neuroinvasive diseases caused by West Nile Virus, among which 9 cases of elderly patients with chronic conditions resulted in a lethal outcome (Institute of Public Health of Serbia, 2014).

In the group of mammalian tick viruses, tick-borne meningo-encephalitis virus (TBEV) has been ranked into the family Flaviviridae, genus Flavivirus, with three subtypes: Far East, Siberian and European subtype. Endemic focal points of this viral infection can be found from Western Europe to China and Japan. Those in Europe are primarily located in Austria, Slovenia, Switzerland, Czech Republic and some countries of ex-Soviet Union. In the last 30 years in Europe, new focal points and a $400 \%$ increase in new cases in endemic areas were registered (ECDC, 2014). Increase in incidence in Czech Republic was explained exclusively by a change in climatic conditions (Daniel et al., 2010). Principal vector species in Europe is tick Ixodes ricinus. In ticks, virus is transmitted by transovarial route, and all stages from larva, via pupa to adult, may be infected and transmit the infection to vertebrates and humans by bite while feeding. The reservoirs include small rodents, mostly members of the species Apodemus, but also some wild and domestic animals, on which adult ticks feed. The disease progress may manifest biphasic course. The European subtype causes milder forms of disease and biphasic course can be noticed in $20-30 \%$ of infected population (ECDC, 2014). After the first phase of illness, characterized by unspecific symptoms - fever, fatigue, malaise, muscle pain, headache - the first symptoms of meningitis, meningoencephalitis, poliomyelitis, and polyradiculoneuropathy with Guillain- Barré like paralysis may arise. More difficult forms of the disease frequently affect elderly patients. First 
serological studies in Serbia pointed out that the activity of the virus in the territory of Vojvodina, where the seroprevalence of IgG antibody is $7.9 \%$ in the residents of South Backa region (Vojvodina, Serbia), while no TBEV-positive serum samples were detected in the region of Nis (Hrnjakovic-Cvjetkovic et al., 2014).

Usutu virus is an ARBO virus from the family Flaviviridae, genus Flavivirus, Japanese encephalitis serogroup. It is maintained (like the West Nile virus) throughout the transmission cycle between wild birds and ornithophilic mosquitoes, mostly from the genus Culex. While in the African birds infection is asymptomatic, the virus is highly virulent for European birds, and causes lethal encephalitis, necrotic hepatitis and degenerative changes in heart and neural tissue (Bakonyi et al., 2007). USUTU virus infection has been established in many bird species in Italy, Austria, Germany, Switzerland, Spain, Hungary, Czech Republic and Poland (Arbeitskreis, 2014). In humans, the virus can cause fever and rash. In immunocompromised patients, pronounced neurological manifestations and a fulminant hepatitis may arise (Cavrini et al., 2009). Medical importance of this ARBO virus in immunocompetent individuals remains to be evaluated. Serological investigation done by ELISA IgG test in humans showed the presence of anti-USUTU virus antibodies in 4.5\% samples out of 88 healthy subjects of South Backa region, Vojvodina, Serbia (Hrnjakovic-Cvjetkovic et al., 2014).

\section{DIAGNOSTIC METHODS}

A clinician's doubt whether there is a vector-transmitted infection, requires laboratory confirmation. The laboratory methods encompass the direct ones determining the virus isolation in cell culture or amplification of the virus genome, and indirect ones, that is, serological methods that detect the presence of specific antibodies. Flavivirus isolation may be performed from blood or cerebrospinal fluid on different cell lines, but only at the early stage of infection, when a patient is in viraemic phase characterized by high virus titre in the blood. In West Nile virus infection, viraemia is typically present during the first four days of illness (Dauphin and Zientara, 2007). Real-time reverse transcription-polymerase chain reaction (RT-qPCR) is a method of choice for the determination of flaviviruses in human plasma, serum and cerebrospinal fluid.

Serological diagnosis for all flavivirus infections that produce encephalitis in humans has a similar approach. In the last few years, specific ELISA tests have been developed for the detection of IgM and IgG antibodies against certain flaviviruses. IgM antibodies against West Nile Virus emerge 2-8 days 
after the onset of illness, similarly to USUTU virus infection. However, a weak point of the ELISA tests is that they cannot completely distinguish between the WNV antibodies and antibodies against other flaviviruses, especially those of the same antigenic complex. Antibodies can persist in the serum for several months after infection. IgM antibodies in WNV infection may be present in serum for as long as a year after the infection (Roehrig et al., 2003). Establishment of an accurate serological diagnosis is difficult, especially in the areas where more than one flaviviruses are circulating, so cross-reactions are possible, as is the case with WNV and TBEV in several European countries. The problem of cross-reaction exists between anti-WNV and anti-USUTU virus antibodies, where expected cross-reaction is higher in IgG than in IgM antibodies. For that reason, it is essential to implement diagnosis of USUTU viral infection and tests that are not yet commercially available for the determination of specific IgM antibodies. By the tests available so far (for IgG antibodies only, for now), both acute and convalescent sera should be analyzed for the presence of USUTU virus, thus monitoring seroconversion of IgG antibodies. Cross-reactions could be resolved by a parallel testing on various flaviviruses using plaque reduction neutralization tests according to the specially defined protocols (Beaty et al., 1995). These tests are more specific as compared to ELISA tests, but they can be performed only in Biosafety level 3 facilities (BSL III). The fact that USUTU virus infection in humans can cause severe neurological syndromes imposes the strong and urgent need for new, accessible and rapid molecular detection methods.

Serological tests are essential for the determination of infection in cases when the viraemic phase is completed. Highly specific tests are required, particularly in countries where the circulation of both USUTU virus and WNV is present (Austria, Belarus, Bulgaria, Czech Republic, Croatia, France, Hungary, Italy, Moldova, Portugal, Romania, Russia, Serbia, Slovakia, Spain and Ukraine). New methods are designed for the identification and differentiation of USUTU virus from other ARBO viruses, particularly members of the Japanese encephalitis serogroup circulating in Europe. Virus monitoring by molecular methods is better with regard to the specificity since there are no cross reactions, but is limited by short viraemic phase. Serology enables the detection of antibodies, which last longer, nonetheless with lower specificity for now, using the inhibition of hem-agglutination or ELISA tests. Each positive serum should be confirmed by plaque reduction neutralization test, a methods that is complex, expansive, time-consuming and accessible only to Biosafety level 3 facilities. 


\section{CONCLUSION}

Ever more frequent reports on the circulation of mosquitoes and ticks transmitting the diseases characteristic for tropical regions (WNV, USUTU, Dengue, Chikungunya etc.) in the European Union advocate the necessity of a more intense and careful preparedness and control of these diseases by new diagnostic procedures and more specific serological tests even in our country. The surveillance program of flaviviruses in our country exists for WNV and encompasses human, veterinarian and entomological monitoring with the aim of early detection of infections in human population, applying serological tests and detection of a viral genome in blood, cerebrospinal fluid in any suspected case of acute meningoencephalitis. The surveillance in animals has been done by passive and active surveillance of horses, chickens and non-migrating wild birds, and entomological surveillance by weekly and monthly trapping of mosquitoes depending on the determined activity in birds, humans and horses, and testing on specific antibody or virus presence. The obtained information about the fluctuations of flavivirus infections in our environment are valuable for modelling the control and surveillance of vectors. It is expected that informative campaigns will lead to the increase in personal protection, and adequate screening tests would prevent infections in the blood, tissue and organ donors.

\section{AKNOWLEDGMENTS}

This work is conducted within the project TR31084 funded by the Serbian Ministry of Education, Science and Technological development

\section{REFERENCES}

1. Arbeitskreis Blut, Untergruppe «Bewertung Blutassoziierter Krankheitserreger»: Usutu virus. Transfus Med Hemother 41, 73-82, 2014.

2. Bakonyi T.: Emergence of Usutu Virus in Hungary. Journal of Clinical Microbiology 45, 12, 3870-3874, 2007.

3. Beaty BJ., Calisher CH., Shope RE. In: Lenette EH, Lenette DA,. Lenette ET, editors. Diagnostic procedures for viral, rickettsial, and chlamydial infections. 7th ed. Washington, DC: American Public Health Association; 1995.

4. Cavrini F., Gaibani P., Longo G., Pierro AM., Rossini G., Bonilauri P.: Usutu virus infection in a patient who underwent orthotropic liver transplantation. Italy. Euro Surveill 14(50):19448, 2009. Available online: http:// 
www.eurosurveillance.org/ViewArticle.aspx?ArticleId=19448

5. Daniel M., Kriz B., Danielova V., Benes C.: Changes of meteorological factors and tick-borne encephalitis incidence in the Czech Republic. Epidemiol Mikrobiol Immunol 59, 179-187, 2010.

6. Dauphin G., Zientara S.: West Nile virus: Recent trends in diagnosis and vaccine development. Vaccine 25, 5563-5576, 2007. Available online at www.sciencedirect.com

7. European Centre for Disease Prevention and Control 2014: Tick-borne encephalitis. Available online:http://www.ecdc.europa.eu/en/healthtopics/ emerging_and_vector-borne_diseases/tick_borne_diseases/tick_borne_ encephalitis

8. Gjenero-Margan I., Aleraj B., Krajcar D., Lesnikar V., Klobucar A.,PemNovosel I., et al.: Autochthonous dengue fever in Croatia, August-September 2010. Euro.Surveill 16, 19805, 1-19805, 4, 2011.

9. Hrnjakovic Cvjetkovic I., Milosevic V., Petrovic V., Kovačevic G., Radovanov J. , Cvjetkovic D. Patic A., Elez I., Stefan Mikic S., Petrovic T., Lazic S., Jovanovic Galovic A., Petric D.: West Nile virus infektion in humans and other vertebrates. Arch.Biol.Sci, Belgrade 66, 1, 37-42., 2014.

10. Hrnjakovic Cvjetkovic I., Patic A., Nikolic N., Radovanov J., Kovacevic G., Jovanovic Galovic A., Cvjetkovic D., Stefan Mikic S., Petric D., Petrovic T., Milosevic V. : Seroprevalence of West Nile Virus and Tick-borne encephalitis virus in Sauth Backa District and Nisava District. In: Book of Abstract, 48 Days of Preventive Medicine, International Congress 23-26 September Nis, Faculty of Medicine, 2014, p35.http://www.izjz-nis.org.rs/ daniprevmed/14/Zbornik

11. Hrnjakovic Cvjetkovic I., Petric D., Petrovic T., Patic A., Nikolic N., Jovanovic Galovic A. et al.: Investigation of seroprevalence of USUTU virus in inhabitants of South Backa Region, Vojvodina, Serbia. In: Tamas Petrovic, Editor in Chief, Book of abstracts, Symposijum XVI Epizootiology days of Serbia 6 - 7 November, Zrenjanin, Section for Zoonoses/Serbian Veterinary Society, 2014, p 96.

12. Institute of Public Health of Serbia "Slobodan Jovanović Batut": Information about the current epidemiological situation of West Nile fever in the territory of the Republic of Serbia in 2014. Available on line: http://www. batut.org.rs/index.php? content $=940$

13. La Ruche G., Souares Y., Armengaud A., Peloux-Petiot F., Delaunay P., Despres P., et al.: First two autochthonous dengue virus infections in metropolitan France September 2010. Euro Surveill 15, 19676,1-19676:5, 2010.

14. Lupulovic D., Martín-Acebes M.A., Lazic S., Alonso-Padilla J., Blazquez 
A.B., Escribano - Romero E. Petrović T., Saiz J.. First Serological Evidence of West Nile Virus Activity in Horses in Serbia. Vector-Borne and Zoonotic Dis. 11, 1303-1305, 2011.

15. Mostashari F., Bunning ML., Kitsutani PT., Singer DA., Nash D., Cooper M.: Epidemic West Nile encephalitis, New York,1999: results of a household-based seroepidemiological survey. Lancet 358(9278), 261-264., 2001.

16. Petric D., Hrnjakovic I., Radovanov J., Cvjetkovic D., Jerant Patic V., Milosevic V, Kovačević G, Zgomba M, Ignjatović Ćupina A, Konjević A, Marinković, D, Paz Sánchez-Seco M. West Nile virus surveillance in humans and mosquitoes and detection of cell fusing agent virus in Vojvodina province (Serbia). HealthMed; 6(2):462-468, 2012.

17. Petrović T., Blázquez AB., Lupulović D., Lazić G., Escribano-Romero E., Fabijan D., Kapetanov M, Lazić S, Saiz JC: Monitoring West Nile virus (WNV) infection in wild birds in Serbia during 2012: first isolation and characterization of WNV strains from Serbia. Euro Surveill 18(44), 2013pii=20622.Available online: http://www.eurosurveillance.org/ ViewArticle.aspx?ArticleId=20622

18. Popović N., Milošević B., Urošević A., Poluga J., Lavadinović L., Nedelijković J., Jevtović D., Dulović O.: Outbreak of West Nile virus infection among humans Serbia, August to October 2012. Euro Surveill 18(43), 2013. Available online: http://www.eurosurveillance.org/ViewArticle. aspx?ArticleId $=20613$

19. Roehrig JT., Nash D., Maldin B., Labowitz A., Martin DA., Lanciotti RS. et al.: Persistence of virus-reactive serum immunoglobulin $\mathrm{M}$ antibody in confirmed West Nile virus encephalitis cases. Emerg Infect Dis 9, 376-379, 2003.

Primljeno: 15.10.2014.

Odobreno: 25.10.2014. 